\title{
FISH of supernumerary marker chromosomes (SMCs) identifies six diagnostically relevant intervals on chromosome $22 q$ and a novel type of bisatellited SMC(22)
}

\author{
Oliver Bartsch ${ }^{\star 1,2}$, Sasan Rasi ${ }^{1}$, Kristina Hoffmann ${ }^{3}$ and Nikolaus Blin ${ }^{3}$
}

\begin{abstract}
${ }^{1}$ Institute for Human Genetics, Mainz University School of Medicine, Mainz, Germany; ${ }^{2}$ Institute of Clinical Genetics, Dresden University of Technology, Dresden, Germany; ${ }^{3}$ Institute of Anthropology and Human Genetics, Eberhard-KarlsUniversity, Tübingen, Germany
\end{abstract}

Supernumerary marker chromosomes (SMCs) are frequently found at pre- and postnatal cytogenetic diagnosis and require identification. A disproportionally large subset of SMCs is derived from the human chromosome 22 and confers tri- or tetrasomy for the cat eye chromosomal region (CECR, the proximal $2 \mathrm{Mb}$ of chromosome 22q) and/or other segments of 22q. Using fluorescence in situ hybridization (FISH) and 15 different DNA probes, we studied nine unrelated patients with an SMC(22) that contained the CECR. Five patients showed the small (type I) cat eye syndrome (CES) chromosome and each one had the larger (type II) CES chromosome, small ring chromosome 22 , der(22)t $(11 ; 22)$ extrachromosome, and a novel type of bisatellited $\operatorname{SMC}(22)$ with breakpoints outside the low-copy repeats (LCRs22). By size and morphology, the novel bisatellited SMC(22) resembled the typical (types I and II) CES chromosomes, but it might have been associated with the chromosome $22 q$ duplication syndrome, not CES. This SMC included a marker from band 22q12.3 and conferred only one extra copy each of the 22 centromere, CECR, and common $22 q 11$ deletion area. There has been no previous report of a bisatellited SMC(22) predicting the chromosome 22q duplication syndrome. Accounting for the cytogenetic resemblance to CES chromosomes but different makeup and prognosis, we propose naming this an atypical (type III) CES chromosome. In this study, we found six distinct intervals on $22 \mathrm{q}$ to be relevant for FISH diagnostics. We propose to characterize $\mathrm{SMCs}(22)$ using DNA probes corresponding to these intervals. European Journal of Human Genetics (2005) 13, 592-598. doi:10.1038/sj.ejhg.5201378

Published online 9 March 2005

Keywords: human chromosome 22; supernumerary marker chromosome; cat eye chromosomal region

\section{Introduction}

Supernumerary marker chromosomes (SMCs) are frequent findings at pre- and postnatal cytogenetic diagnosis. Their composition is diverse and requires identification, typically by fluorescence in situ hybridization (FISH). An overpropor-

*Correspondence: Priv-Doz Dr O Bartsch, Institut für Humangenetik Universitätsklinikum, Langenbeckstrasse 1, Mainz D-55101, Germany. Tel: +496131 17 5791; Fax: + 49613117 5790;

E-mail: bartsch@humgen.klinik.uni-mainz.de

Received 29 September 2004; revised 23 December 2004; accepted 23 December 2004 tionally large subset of SMCs, approximately $9 \%,{ }^{1}$ is derived from chromosome 22 and a subset of these SMCs(22) confers tri- or tetrasomy for the cat eye chromosomal region (CECR) that encompasses the proximal $2 \mathrm{Mb}$ of chromosome $22 \mathrm{q}$ (from the centromere to D22S57). ${ }^{2,3}$ Owing to their small size and complex rearrangements, $\operatorname{SMCs}(22)$ have remained a diagnostic challenge. No specific diagnostic test and no specific DNA probe for the CECR can be commercially purchased, and cosmid clones such as $\cos 121,{ }^{4,5} \mathrm{H} 9 ; 72$, $\mathrm{H} 7 ; 48$, and $\mathrm{E}^{6}$ are neither generally available nor is their molecular content defined by current standards. Moreover, a 
number of different SMCs containing the CECR have been described, including the typical bisatellited small (type I) and larger (type II) cat eye syndrome (CES) chromosomes, ${ }^{5-9}$ small ring-like SMCs(22), ${ }^{2}$ and others, ${ }^{10,11}$ warranting FISH studies with several DNA probes.

The typical CES chromosomes are formed from breakpoints within band 22q11.2 in each of two sister or nonsister chromatids. ${ }^{8,9}$ The most common breakpoint interval is a region that corresponds to the proximal breakpoint interval in the 22q11 deletion syndrome (DiGeorge/velocardiofacial syndrome, DG/VCFS), and the distal (type II) breakpoint interval coincides with the distal breakpoint interval in the DG/VCFS. Therefore, Mc Taggart et $a l^{9}$ classified the CES chromosomes into two types based on the location of the two breakpoints required to generate them. The small (type I) CES chromosomes are symmetrical, with both breakpoints located within the proximal interval, and the larger (type II) CES chromosomes are either asymmetrical, with one breakpoint located in each of the two intervals, or symmetrical, with both breakpoints located in the distal interval. The colocalization of the breakpoints in the different syndromes and the presence of low-copy repeats (LCR22s) at each interval indicated the existence of several specific regions of chromosomal instability in $22 \mathrm{q} 11.2$, which are involved in the production of both deletions and duplications. ${ }^{12}$

The different SMCs(22) are associated with phenotypes ranging from the normal development to syndromic severe mental retardation (MR). The CES phenotype (MIM $115470)$ is highly variable and includes ocular coloboma, mild hypertelorism, preauricular skin tags and/or pits, cardiac defects, anal atresia, and urogenital anomalies. The mental outcome can be normal; $44 \%$ of patients showed normal or borderline normal mental development, $48 \%$ mild or moderate MR, and 7\% severe MR. ${ }^{13,14}$ Based on the variable appearance and genetic content of the CES SMCs, a relation between the different forms of the CES SMCs and the variations in the severity of the CES phenotype was considered, but no correlation was found. ${ }^{14,15}$ The majority of SMCs(22) reported to date contain two copies of the CECR rendering the patients tetrasomic for this region; a few patients display one copy making them trisomic. ${ }^{2,16,17}$

We performed FISH studies on nine unrelated patients with an SMC comprising one or two extra copies of the CECR. Five patients showed the smaller (type I) CES chromosome and each one demonstrated the larger (type II) CES chromosome, small ring-like $\mathrm{SMC}(22), \operatorname{der}(22) \mathrm{t}(11 ; 22)$ extrachromosome, and a novel type of bisatellited SMC(22) that we designated atypical (type III) CES chromosome.

\section{Materials and methods} Study and subjects

This study was approved by the Ethics Committee of the Medical Faculty at Dresden on the basis that the FISH studies represented innovative diagnostics and were performed using existing specimens, without additional withdrawal of materials from patients. Using FISH, we studied 57 pre- or postnatally detected SMCs from unrelated subjects. In all, 17 SMCs (29.8\%) were identified as SMCs(22). Of these, seven were isochromosomes $22 \mathrm{p}$ (bisatellited, CECR absent) and 10 showed one or two extra copies of the CECR. This study included nine out of the 10 patients with partial tri- or tetrasomy of 22q. One case of $\operatorname{der}(22) \mathrm{t}(11 ; 22)$ extrachromosome was not studied because of lack of materials. Seven subjects were referred for FISH diagnostics after an amniocentesis and karyotyping performed elsewhere, and two subjects were patients at the Institute of Clinical Genetics at Dresden. Table 1 indicates clinical and cytogenetic findings.

\section{FISH}

FISH was performed using a previously described proto$\mathrm{col}^{18}$ with metaphase spreads from amniocytes or cultured blood lymphocytes (patients 4 and 5). DNA probes included eight established probes ${ }^{19-21}$ and seven BAC clones not previously used for FISH (CTA-639G4, 115F6, 770H11, 919E7, 217D6, 966B6, and 256C5). ${ }^{21}$ Table 2 provides properties of the probes and the order of location from 22pter. After preselecting 20 BACs from the CTA library based on their size and location on the human chromosome $22 \mathrm{q}^{21}$ and testing each clone using FISH on 25 normal controls, we selected 12 BACs (including the previously described clones 678G6, 201C11, 219G6, 384D8, and 799F10) ${ }^{19,20}$ that showed clear FISH signals, no variation of hybridization at normal 22s, and no second sites at other chromosomes. Cosmid/BAC DNA was amplified using a degenerate oligonucleotide primed shuttle polymerase chain reaction (DOP-shuttle-PCR) protocol. ${ }^{18,22}$ Each probe lot was tested on a normal control before use. Image capture and analysis was performed using Axiophot epifluorescence microscopes (Carl Zeiss, Göttingen, Germany) and the ISIS digital imaging system (MetaSystems, Altlussheim, Germany).

\section{Results}

Table 1 indicates clinical and cytogenetic findings, Table 2 provides properties of the DNA probes used, and Table 3 summarizes the results after FISH. Figure 1 depicts the atypical (type III) CES chromosome of patient 7 using GTG banding and Figure 2 shows examples after FISH.

The probes represented six distinct intervals at chromosome 22q (Table 2): (1) No. 1690612 and P5032 detected the centromeric heterochromatin. (2) Cosmid cos121 and BACs 639G4, 115F6, and 678G6 each hybridized to all CECR-containing SMCs(22) (patients 1-9), regardless of type I or type II CES chromosome, ${ }^{9}$ small ring-like SMC(22), or other. These clones detect the CECR. $(3,4)$ BACs 201C11, 919E7, 770H11, and 219G6 each yielded 
Table 1 Clinical features of patients, cytogenetic description of marker chromosomes, and final karyotypes

\begin{tabular}{|c|c|c|}
\hline Patient & $\begin{array}{l}\text { Cytogenetic } \\
\text { description }\end{array}$ & Karyotype and clinical features \\
\hline 1 & SBMC & $\begin{array}{l}47, \mathrm{XY},+ \text { mar.ish idic(22)(q11.21)(D14Z1/D22Z1++,Z00042++, HCF2-) de novo } \\
\text { Amniocentesis because of advanced maternal age ( } 40 \text { years), abnormal foetal ultrasound showing } \\
\text { hypoplastic right heart and anal atresia, termination of pregnancy }\end{array}$ \\
\hline 2 & SBMC & $\begin{array}{l}\text { 47, XY, +mar[17]/46,XY[17].ish idic(22)(q11.21)(D22Z2++,D14Z1/D22Z1++, RH74651/D22S543++, } \\
\text { Z00042++, CTA-115F6++,D22S627++,D22S553/D22S609-,CTA-770H11-) de novo } \\
\text { Amniocentesis because of advanced maternal age (39 years), normal foetal ultrasound, live born, mild } \\
\text { CES at the age of } 1.5 \text { years reported on telephone interview, detailed phenotype not available }\end{array}$ \\
\hline 4 & SBMC & $\begin{array}{l}\text { 47,XY,+mar.ish idic(22)(q11.21)(D14Z1/D22Z1++, RH74651/D22S543++,Z00042++,CTA-115F6++, } \\
\text { D22S627++,D22S553/D22S609-,CTA-770H11-,HCF2-) de novo } \\
\text { Newborn with preauricular pits, low set abnormally shaped ears, and anal atresia }\end{array}$ \\
\hline 5 & SBMC & $\begin{array}{l}47, \mathrm{XX},+ \text { mar.ish idic(22)(q11.21)(D22Z2++,D14Z1/D22Z1++, RH74651/D22S543++,Z00042++, } \\
\text { CTA-115F6++,D22S627++,D22S553/D22S609-,CTA-770H11-) de novo } \\
\text { Obese woman aged } 18 \text { years, height } 170.4 \mathrm{~cm}\left(90 \text { th percentile), weight } 93.1 \mathrm{~kg}\left(\mathrm{BMI} 32 \mathrm{~kg} / \mathrm{m}^{2}\right) \text {, right }\right. \\
\text { eye microphthalmos, severe cataract, coloboma of iris, and no fixation; left eye coloboma of iris and } \\
\text { choroid, nystagm; right ear preauricular tag, atretic auditory meatus, and sensory deafness; left ear } \\
\text { dysplastic, preauricular fistula and tag, and normal hearing. Normal heart. Blindness from the age of } 10 \\
\text { years after minor trauma and retinal detachment on the left. Normal puberty and menarche at the age } \\
\text { of } 13 \text { years, normal intelligence, very clear speech, very good vocabulary, and normal performance at a } \\
\text { school for the blind with good marks on the final exams }\end{array}$ \\
\hline 6 & SBMC & $\begin{array}{l}47, \mathrm{XY},+ \text { mar.ish idic(22)(q11.21)(D14Z1/D22Z1++, RH74651/D22S543++,CTA-115F6++,D22S627++, } \\
\text { D22S553/D22S609++,D22S942/D22S941+ or ++,CTA-770H11+or ++,HCF2+ or ++,CTA-799F10-) de } \\
\text { novo } \\
\text { Amniocentesis because of advanced maternal age ( } 37 \text { years), normal detailed foetal ultrasound at } 14+5 \\
\text { weeks of gestation showing no anomalies, and predicting a foetal weight of } 112 \mathrm{~g} \text { (low normal range). } \\
\text { At the genetic counseling, the woman considered the termination of the pregnancy. She was not } \\
\text { available for follow-up }\end{array}$ \\
\hline 7 & SBMC & $\begin{array}{l}47, \mathrm{XY},+\operatorname{mar}[11] / 46, \mathrm{XY}[46] . \text { ish der(22)(pter } \rightarrow \mathrm{q} 12.3: \mathrm{p} 11.2 \rightarrow \text { pter)(D14Z1/D22Z1+, } \\
\mathrm{RH} 74651 / \mathrm{D} 22 \mathrm{~S} 543+, \mathrm{Z} 00042+, \mathrm{CTA}-115 \mathrm{~F} 6+, \mathrm{D} 22 \mathrm{~S} 627+, \mathrm{D} 22 \mathrm{~S} 553 / \mathrm{D} 22 \mathrm{~S} 609+, \mathrm{BCR} 1 / \mathrm{D} 22 \mathrm{~S} 257+, \\
\mathrm{D} 22 \mathrm{~S} 301+, \mathrm{D} 22 \mathrm{~S} 102 / \mathrm{CSF} 2 \mathrm{RB}+, \mathrm{ECGF} 1 / \mathrm{ARSA}-, \mathrm{CTA}-799 \mathrm{~F} 10-) \text { de novo } \\
\text { Amniocentesis because of advanced maternal age (37 years), normal foetal ultrasound, premature } \\
\text { delivery at } 33 \text { weeks, normal birth weight at } 2000 \mathrm{~g} \text {, and not dysmorphic. Normal development at the } \\
\text { age of } 6 \text { months reported on telephone interview }\end{array}$ \\
\hline
\end{tabular}

SBMC $=$ supernumerary bisatellited marker chromosome.

hybridization signals only at two out of the seven bisatellited SMCs(22) (patients 6 and 7) and at the ring chromosome 22 (patient 8). These BACs map to the middle section of band 22q11.21 and define the type II CES SMC area, also known as the interval of the common $22 \mathrm{q} 11$ deletion. ${ }^{9,19,23,24}$ The breakpoint of the constitutional 11;22 translocation (patient 9) was located within this cluster in between BACs $919 \mathrm{E} 7$ (present on the der(22)) and 219G6 (absent from the der(22)). This breakpoint colocalized with the distal breakpoint area of the proximal $22 \mathrm{q} 11$ deletion. ${ }^{19}$ (5) BACs 217D6, 966B6, and 256C5 hybridized only to the unusual bisatellited SMC (Figure 1) of patient 7 and to the ring-like SMC(22) of patient 8. (6) The most distal clones, 384D8 and 799F10, were absent from all SMCs in this study.

\section{Discussion}

We report FISH studies of different SMCs(22) conferring trior tetrasomy for the CECR from nine unrelated subjects. One of these SMCs, a bisatellited SMC(22) predicting 22q duplication syndrome (case 7), has not been described previously. The small (type I) bisatellited CES chromosome, defined by both breakpoints located between BAC clones 
Table 2 Properties of DNA probes used in this study, listed in order of location from 22pter

\begin{tabular}{|c|c|c|c|c|c|}
\hline Probe & Size $(k b)$ & Marker (other name) & $\begin{array}{l}\text { Distance from } \\
22 \text { pter }\end{array}$ & Chromosome & $\begin{array}{l}\text { Diagnostic properties (see the } \\
\text { Discussion) }\end{array}$ \\
\hline $\begin{array}{l}\text { No. } 1690612 \\
\text { P5032 }\end{array}$ & $\begin{array}{l}? \\
?\end{array}$ & $\begin{array}{l}\text { D22Z2 } \\
\text { D14Z1 } \\
\text { D22Z1 }\end{array}$ & $\begin{array}{l}\sim 9.600-14.400 \mathrm{Mb} \\
\text { Not relevant } \\
\sim 9.600-14.400 \mathrm{Mb}\end{array}$ & $\begin{array}{l}\text { 22cen } \\
\text { 14cen } \\
22 \text { cen }\end{array}$ & $\begin{array}{l}\text { Interval 1: centromere any } \\
\text { heterochromatin, present on } \\
\text { SMC }(22)\end{array}$ \\
\hline CTA-639G4 & 80 & $\begin{array}{l}\text { RH74651 (F8WWFP) } \\
\text { D22S543 }\end{array}$ & $\begin{array}{l}15.543 \mathrm{Mb} \\
15.547 \mathrm{Mb}\end{array}$ & $\begin{array}{l}22 q 11.1 \\
22 q 11.1\end{array}$ & $\begin{array}{l}\text { Interval 2: CECR, present on CES } \\
\text { chromosomes of any kind }\end{array}$ \\
\hline $\cos 121$ & $?$ & $\begin{array}{l}\text { Z00042 } \\
(I G K V 3 O R 22-2)\end{array}$ & $\begin{array}{l}15.781- \\
15.782 \mathrm{Mb}^{\mathrm{b}}\end{array}$ & $22 q 11.1$ & \\
\hline CTA-115F6 & 186 & $\begin{array}{l}\text { CTA-115F6 } \\
\text { D22S420 } \\
\text { D22S137 }\end{array}$ & $\begin{array}{l}16.153-16.340 \mathrm{Mb} \\
16.233 \mathrm{Mb} \\
16.268 \mathrm{Mb}\end{array}$ & $\begin{array}{l}22 q 11.1-q 11.21 \\
22 q 11.1 \\
22 q 11.1\end{array}$ & \\
\hline CTA-678G6 & 125 & D22S627 (WI-352) & $16.688 \mathrm{Mb}$ & $22 q 11.21$ & \\
\hline CTA-201C11 & 189 & $\begin{array}{l}\text { D22S553 } \\
\text { D22S609 (WI-326) } \\
\text { HIRA }\end{array}$ & $\begin{array}{l}17.690 \mathrm{Mb} \\
17.711 \mathrm{Mb} \\
17.692-17.793 \mathrm{Mb}\end{array}$ & $\begin{array}{l}22 q 11.21 \\
22 q 11.21 \\
22 q 11.21\end{array}$ & $\begin{array}{l}\text { Interval 3: present on and on } \\
\text { der(22)t(11;22) chromosomes } \\
\text { larger (type II) CES }\end{array}$ \\
\hline CTA-919E7 & 95 & $\begin{array}{l}\text { D22S942 } \\
\text { D22S941 }\end{array}$ & $\begin{array}{l}17.776 \mathrm{Mb} \\
17.784 \mathrm{Mb}\end{array}$ & $\begin{array}{l}22 q 11.21 \\
22 q 11.21\end{array}$ & $\begin{array}{l}\text { chromosomes; absent from } \\
\text { small (type I) CES } \\
\text { chromosomes, proximal 22q11 } \\
\text { deletion chromosomes, and } \\
\text { common } 22 q 11 \text { deletion } \\
\text { chromosomes }\end{array}$ \\
\hline $\begin{array}{l}\text { CTA-770H11 } \\
\text { CTA-219G6 }\end{array}$ & $\begin{array}{l}142 \\
220\end{array}$ & $\begin{array}{l}\text { CTA-770H11 } \\
\text { HCF2 }\end{array}$ & $\begin{array}{l}19.197-19.339 \mathrm{Mb} \\
19.458-19.466 \mathrm{Mb}\end{array}$ & $\begin{array}{l}22 q 11.21 \\
22 q 11.21\end{array}$ & $\begin{array}{l}\text { Interval 4: present on larger } \\
\text { (type II CES) chromosome and } \\
\text { on proximal 22q11 deletion } \\
\text { chromosomes; absent from } \\
\text { small (type I) CES } \\
\text { chromosomes, der(22)t }(11 ; 22) \\
\text { chromosomes, and common } \\
22 q 11 \text { deletion chromosomes }\end{array}$ \\
\hline CTA-217D6 & 270 & $\begin{array}{l}\text { BCR1 } \\
\text { D22S257 (MFD51) }\end{array}$ & $\begin{array}{l}21.847-21.982 \mathrm{Mb} \\
21.892 \mathrm{Mb}\end{array}$ & $\begin{array}{l}22 q 11.23 \\
22 q 11.23\end{array}$ & $\begin{array}{l}\text { Interval 5: present on atypical } \\
\text { (type III) CES chromosome and }\end{array}$ \\
\hline $\begin{array}{l}\text { CTA-966B6 } \\
\text { CTA-256C5 }\end{array}$ & $\begin{array}{l}33 \\
200\end{array}$ & $\begin{array}{l}\text { D22S301 } \\
\text { D22S102 } \\
\text { CSF2RB }\end{array}$ & $\begin{array}{l}\text { Not mapped } \\
35.641 \mathrm{Mb} \\
35.642-35.659 \mathrm{Mb}\end{array}$ & $\begin{array}{l}22 q 11.23 \\
22 q 12.3 \\
22 q 12.3\end{array}$ & $\begin{array}{l}\text { on common } 22 q 11 \text { deletion } \\
\text { chromosomes; absent from } \\
\text { usual (type I and type II) CES } \\
\text { chromosomes }\end{array}$ \\
\hline CTA-384D8 & 140 & $\begin{array}{l}\text { ECGF1 } \\
\text { ARSA }\end{array}$ & $\begin{array}{l}49.254-49.258 \mathrm{Mb} \\
49.353-49.356 \mathrm{Mb}\end{array}$ & $\begin{array}{l}22 q 13.33 \\
22 q 13.33\end{array}$ & $\begin{array}{l}\text { Interval 6: contains a marker } \\
\text { mapping within } 300 \mathrm{~kb} \text { of the }\end{array}$ \\
\hline CTA-799F10 & 67 & CTA-799F10 & $49.369-49.436 \mathrm{Mb}$ & $22 q 13.33$ & $\begin{array}{l}\text { end of the chromosome, may } \\
\text { be used for subtelomere FISH }\end{array}$ \\
\hline
\end{tabular}

a Using the UCSC Genome Browser (http://genome.ucsc.edu/cgi-bin/hgGateway), May 2004 assembly based on NCBI Build 35, September 16, 2004.

bUsing the Entrez Nucleotides database (http://www.ncbi.nlm.nih.gov/entrez) and BLASTN search against NT_011519.10.

678G6 and 201C11 (Table 2), was detected in five subjects, emphasizing that type I CES chromosomes are the most common cause of CES. ${ }^{7-9}$ In silico data on the BAC clones (Table 2) place the breakpoint of the type I CES chromosomes between markers D22S627 (16.688 Mb, using NCBI build 35$)$ and D22S553 $(17.690 \mathrm{Mb})$. These data are in line with the molecular data placing the breakpoint at the LCRA (between D22S427 and D22S36) ${ }^{9,25}$ and correspond to the recently defined LCR22-3a $(17.248-17.433 \mathrm{Mb}) .^{26}$

We detected only one larger (type II) CES chromosome (patient 6), a low rate not reported elsewhere. ${ }^{8,9}$ Our data place the distal breakpoint of the type II CES chromosome between markers HCF2 (19.466 Mb) and BCR1 (21.847 Mb), matching the molecular positions of the LCR-D (between CRKL and D22S112) ${ }^{9,25}$ and the LCR22-6 (20.347$20.529 \mathrm{Mb}){ }^{26}$ Patients 8 and 9 demonstrated a ring-like SMC and a der(22) extrachromosome, respectively. The ring-like SMC was small by cytogenetic standards, but contained band 22q11.23 using FISH. Thus, this SMC probably contained more euchromatin than a previously reported $\mathrm{SMC}^{2}$ and predicted a phenotype of chromosome $22 q$ duplication syndrome. ${ }^{27-29}$ Further findings (patient 9) located the breakpoint of the constitutional $11 ; 22$ translocation between markers D22S942 (17.784 Mb) and 
Table 3 Results of FISH studies

\begin{tabular}{|c|c|c|c|c|c|c|c|c|c|}
\hline \multirow[t]{2}{*}{ Probe } & Patient 1 & Patient 2 & Patient 3 & Patient 4 & Patient 5 & Patient 6 & Patient 7 & Patient 8 & Patient 9 \\
\hline & $\begin{array}{c}\text { CES SMC } \\
\text { type I }\end{array}$ & $\begin{array}{c}\text { CES SMC } \\
\text { type I }\end{array}$ & $\begin{array}{c}\text { CES SMC } \\
\text { type I }\end{array}$ & $\begin{array}{c}\text { CES SMC } \\
\text { type I }\end{array}$ & $\begin{array}{c}\text { CES SMC } \\
\text { type I }\end{array}$ & $\begin{array}{c}\text { CES SMC } \\
\text { type II }\end{array}$ & $\begin{array}{c}\text { CES SMC } \\
\text { type III }\end{array}$ & $r(22)$ & $\begin{array}{c}\operatorname{der}(22) \\
t(11 ; 22)\end{array}$ \\
\hline No. 1690612 & & ++ & & & ++ & & & + & + \\
\hline P5032 & ++ & ++ & ++ & ++ & ++ & ++ & + & + & + \\
\hline CTA-639G4 & & ++ & ++ & ++ & ++ & ++ & + & & \\
\hline $\cos 121$ & ++ & ++ & ++ & ++ & ++ & & + & + & \\
\hline CTA-115F6 & & ++ & ++ & ++ & ++ & ++ & + & & \\
\hline CTA-678G6 & & ++ & ++ & ++ & ++ & ++ & + & & \\
\hline CTA-201C11 & & - & - & - & - & ++ & + & + & + \\
\hline CTA-919E7 & & & & & & + or ++ & & & + \\
\hline СТА-770H11 & & - & - & - & - & + or ++ & & & \\
\hline CTA-219G6 & - & & - & - & & + or ++ & & + & - \\
\hline CTA-217D6 & & & & & & & + & + & \\
\hline CТА-966B6 & & & & & & & + & + & \\
\hline CTA-256C5 & & & & & & & + & & \\
\hline CTA-384D8 & & & & & & & - & - & - \\
\hline CTA-799F10 & & & & & & - & - & & \\
\hline
\end{tabular}

$-=$ absent from the marker chromosome.

$+=$ one copy present on the marker chromosome.

$++=$ two copies present on the marker chromosome.

+ or $++=$ one or two copies present on the marker chromosome, dosage estimate of hybridization signals not feasible.
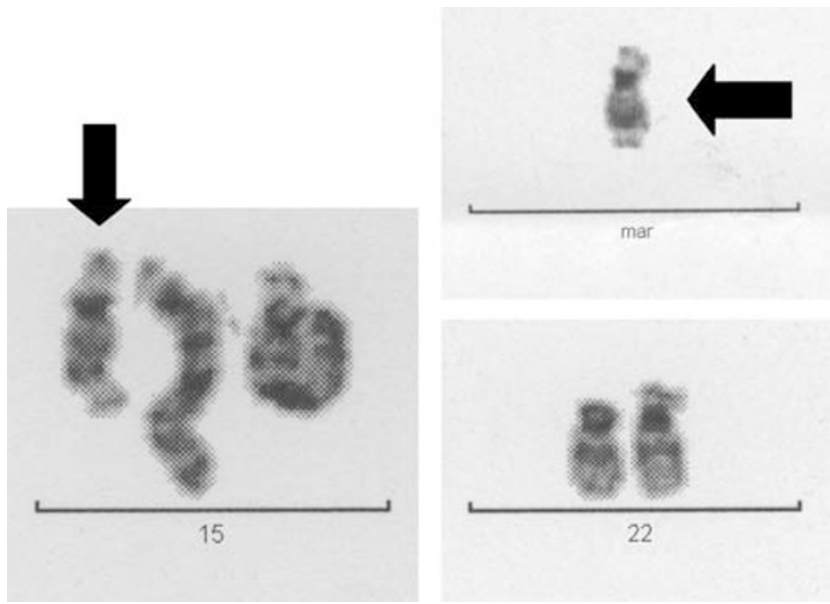

Figure 1 SMC of patient 7 using GTG banding. Left, SMC (arrow) aligned to chromosomes 15 because a dicentric chromosome $15 q 11$ or $15 q 13$ was suspected before FISH. Right, SMC (arrow) and chromosomes 22 from another metaphase. Note the bisatellited symmetrical appearance of this $\operatorname{SMC}(22)$, warranting its designation as a novel (type III) CES chromosome.

HCF2 (19.458 Mb), which is in line with the molecular positions of the LCR-B ${ }^{9,25}$ and the LCR22-4 (18.164$18.409 \mathrm{Mb}) .^{26}$

The SMC of patient 7 resembled the (type I or II) CES chromosomes in size and morphology. ${ }^{6-9}$ However, using FISH this SMC included a marker from chromosome 22q12.3 and conferred only one extra copy each of the centromeric heterochromatin, the CECR, and the area of the common 22q11 deletion. Thus, it represented a deleted
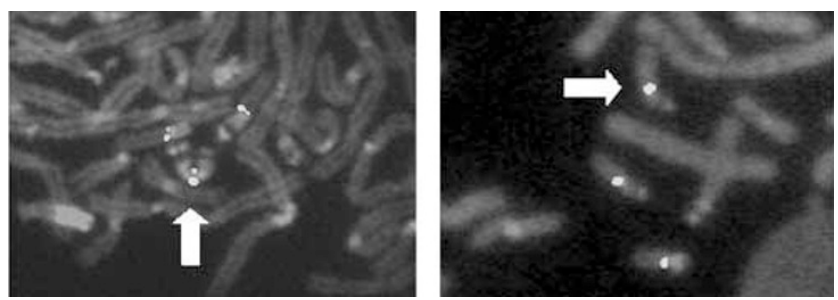

Figure 2 Examples of FISH results. Left, BAC $678 \mathrm{G} 6$ hybridized to the small (type I) CES chromosome of patient 2, note two extra copies present on the SMC (arrow). Right, BAC 678G6 hybridized to the atypical (type III) CES chromosome of patient 7, showing one extra copy (arrow). Note: dosage estimates of hybridization signals were made using several metaphases.

chromosome 22q12.3 with satellites at both ends. The SMC was present only in a small subset of cells (19\% of amniocytes) and the phenotype of the patient at the age of 6 months was normal (Table 1). Nevertheless, this SMC conferred trisomy of 22p11-q12.3 and would predict, if present in all cells, the chromosome $22 \mathrm{q}$ duplication syndrome. $^{27-29}$ Owing to the morphology resembling CES chromosomes but different makeup and prognosis, we suggest naming this SMC an atypical (type III) CES chromosome, defined by at least one breakpoint outside the LCRs22.

Molecular approaches indicated a set of common chromosome breakpoints that are shared between the CES, der(22) syndrome, DG/VCFS, and 22q11 microduplication syndrome. Most CES and DG/VCFS rearrangements were reported to occur by near-homologous recombination at two distinct LCRs22, the proximal 
LCR-A and the distal LCR-D, while nonhomologous recombination at another low-copy repeat, LCR-B, was reported to lead to the constitutional 11;22 translocation..$^{9,24,25,30}$ From the perspective of FISH diagnostics, the DNA probes used here defined six distinct intervals on chromosome 22q (Table 2). We observed no SMC(22) that contained euchromatin between interval 1 (centromere heterochromatin) and interval 2 (the CECR), that is, that had some detectable euchromatin, but not from the cat eye region. The BACs 639G4, 115F6, and 678G6 (interval 2) each identified all SMCs in this study and detected the part of the CECR that is present on small (type I) CES chromosomes. ${ }^{9}$

BACs 201C11, 919E7, 770H11, and 219G6 (intervals 3 and 4) each represented the euchromatin that is specific to the larger (type II) CES chromosomes. The breakpoint area of the constitutional 11;22 translocation differs from the typical CES breakpoints and corresponds with the nested distal breakpoints of the proximal 22q11 deletion, which is present in about $10 \%$ of patients with DG/VCFS. ${ }^{19,24,31}$ Here, we found the BACs 201C11 and 919E7 (interval 3) present on the der(22)t(11;22) extrachromosome. This finding is in line with results from the proximal 22q11 deletion ${ }^{19}$ and a position of the $t(11 ; 22)$ breakpoint area at the LCR-B ${ }^{25}$ or LCR22- $4 .^{26}$

BACs 217D6, 966B6, 256C5, 384D8, and 799F10 (intervals 5 and 6) defined the segment of 22q that is lacking on type II CES chromosomes. The proximal part of this segment was present on the novel (type III) CES chromosome (patient 7) and on the ring-like SMC (patient 8). The two most distal BACs, 384D8 and 799F10 (interval 6), were absent from all SMCs. Initially, the clone 799F10 was not well mapped, ${ }^{21}$ and electronic databases suggested a position of up to $3 \mathrm{Mb}$ distal to BAC 384D8. However, by current data 384D8 and 799F10 are neighbour clones mapping within $300 \mathrm{~kb}$ of the telomere. These data qualify BACs 384D8 and 799F10 for subtelomere FISH studies of chromosome $22 \mathrm{q} \cdot{ }^{20}$

The phenotypes of partial trisomy 22q include the CES, the der(22) syndrome, $^{10}$ the microduplication 22q11.2 syndrome, ${ }^{32}$ and the chromosome $22 \mathrm{q}$ duplication syndrome/s. Full trisomy 22 typically results in abortion, but partial $22 \mathrm{q}$ trisomy including the distal chromo some $22 \mathrm{q} 11.2$ and/or parts of $22 \mathrm{q} 12-\mathrm{q} 13$ was reported with phenotypes that were compatible with survival: the chromosome 22q duplication syndrome/s. ${ }^{27-29}$ The phenotypes of our patients (Table 1) are in line with previous reports. Patients 4 and 5 showed the same cytogenetic anomaly: a type I CES chromosome in all cells. Patient 4 had more severe malformations, reflecting the phenotypic variability in CES. Patient 5 dealt with her different handicaps, which included blindness from the age of 10 years, in an exemplary manner, and shows that a normal mental outcome can be achieved by some patients with CES.
Cytogenetic mosaicism significantly influences the clinical outcome of patients with an SMC. In patient 7 , we consider the normal phenotype to be most likely due to his cytogenetic mosaicism (only 19\% abnormal amniocytes). He was last seen as an infant and remains at risk for late manifestations such as developmental delay. Patient 9 showed the der(22) syndrome. The der(22) syndrome and CES share a similar region of extra dosage on chromosome 22q11.21, but the der(22) syndrome is always associated with a partial trisomy of $11 \mathrm{q} 23.3 \rightarrow$ qter in addition to the partial trisomy of 22 pter $\rightarrow \mathrm{q} 11.21$. The resulting phenotypes differ significantly: the der(22) syndrome is more severe than the CES and includes numerous additional signs that can be attributed to the partial trisomy of $11 \mathrm{q}^{10,11,30}$ such as congenital hernia of diaphragm, renal dysplasia, and multiple renal cysts (patient 9). We have only sporadic data of the other subjects, which mainly represented prenatal diagnoses precluding detailed phenotypic description. Despite the uncertainties of the predicted phenotypes, the clinical colleagues regarded the detailed FISH results as very helpful for the genetic counselling.

\section{Acknowledgements}

We thank Arleta Frensel for technical assistance, Professor Georg Klaus Hinkel and Dr Gabriele Hickmann for contributing clinical data and Figure 1, and Glenis Wiebe for comments on this paper. This work was supported by a grant (BEO 0311211) from the Bundesminister für Bildung und Forschung (www.bmbf.de) to $\mathrm{NB}$ and $\mathrm{OB}$.

\section{Electronic-database information}

URLS and accession numbers for data in this article are as follows: Online Mendelian Inheritance in Man (OMIM, http://www.ncbi.nlm.nih.gov/Omim) for the CES [MIM 115470] and Ensembl (http:// www.ensembl.org/Homo_sapiens/) and the UCSC Genome Browser (http://genome.ucsc.edu/cgi-bin/hgGateway) for genetic and physical positions of loci on chromosome 22.

\section{References}

1 Crolla JA, Youings SA, Ennis S, Jacobs PA: Supernumerary marker chromosomes in man: parental origin, mosaicism and maternal age revisited. Eur J Hum Genet 2004, Oct 27 (Epub ahead of print).

2 Mears AJ, el-Shanti H, Murray JC, McDermid HE, Patil SR: Minute supernumerary ring chromosome 22 associated with cat eye syndrome: further delineation of the critical region. Am J Hum Genet 1995; 57: 667-673.

3 Footz TK, Brinkman-Mills P, Banting GS et al: Analysis of the cat eye syndrome critical region in humans and the region of conserved synteny in mice: a search for candidate genes at or near the human chromosome 22 pericentromere. Genome Res 2001; 11: 1053-1070.

4 Lötscher E, Grzeschik KH, Bauer HG, Pohlenz HD, Straubinger B, Zachau HG: Dispersed human immunoglobulin kappa lightchain genes. Nature 1986; 320: 456-458.

5 Liehr T, Pfeiffer RA, Trautmann U: Typical and partial cat eye syndrome: identification of the marker chromosome by FISH. Clin Genet 1992; 42: 91-96.

6 Crolla JA, Howard P, Mitchell C, Longe FL, Dennis NR: A molecular and FISH approach to determining karyotype and 
phenotype correlations in six patients with supernumerary marker(22) chromosomes. Am J Med Genet 1997; 12: 440-447.

7 Schinzel A, Schmid W, Fraccaro M et al: The 'cat eye syndrome': dicentric small marker chromosome probably derived from a no.22 (tetrasomy 22pter to q11) associated with a characteristic phenotype. Report of 11 patients and delineation of the clinical picture. Hum Genet 1981; 57: 148-158.

8 Mears AJ, Duncan AM, Budarf ML et al: Molecular characterization of the marker chromosome associated with cat eye syndrome. Am J Hum Genet 1994; 55: 134-142.

9 McTaggart KE, Budarf ML, Driscoll DA, Emanuel BS, Ferreira P, McDermid HE: Cat eye syndrome chromosome breakpoint clustering: identification of two intervals also associated with 22q11 deletion syndrome breakpoints. Cytogenet Cell Genet 1998; 81: $222-228$.

10 Aurias A, Turc C, Michiels Y, Sinet PM, Graveleau D, Lejeune J: Deux cas de trisomie $11 \mathrm{q}(\mathrm{q} 231 \rightarrow \mathrm{qter})$ par translocation $\mathrm{t}(11 ; 22)(\mathrm{q} 231 ; \mathrm{q} 111)$ dans deux familles differentes. Ann Genet 1975; 18: $185-188$.

11 Fraccaro M, Lindsten J, Ford CE, Iselius L: The 11q;22q translocation: a European collaborative analysis of 43 cases. Hum Genet 1980; 56: 21-51.

12 McDermid HE, Morrow BE: Genomic disorders on 22q11. Am J Hum Genet 2002; 70: 1077-1088.

13 Hastings RJ, Nisbet DL, Waters K, Spencer T, Chitty LS: Prenatal detection of extra structurally abnormal chromosomes (ESACs): new cases and a review of the literature. Prenat Diagn 1999; 19: $436-445$.

14 Rosias PPR, Sijstermans JMJ, Theunissen PMVM et al: Phenotypic variability of the cat eye syndrome. Case report and review of the literature. Genet Couns 2001; 12: 273-282.

15 Urioste M, Visedo G, Sanchis A et al: Dynamic mosaicism involving an unstable supernumerary $\operatorname{der}(22)$ chromosome in cat eye syndrome. Am J Med Genet 1994; 49: 77-82.

16 Reiss JA, Weleber RG, Brown MG, Bangs CD, Lovrien EW, Magenis RE: Tandem duplication of proximal 22q: a cause of cat-eye syndrome. Am J Med Genet 1985; 20: 165-171.

17 Meins M, Burfeind P, Motsch S et al: Partial trisomy of chromosome 22 resulting from an interstitial duplication of $22 \mathrm{q} 11.2$ in a child with typical cat eye syndrome. J Med Genet 2003; 40: e62.

18 Bartsch O, Wagner A, Hinkel GK et al: FISH studies in 45 patients with Rubinstein-Taybi syndrome: deletions associated with polysplenia, hypoplastic left heart and death in infancy. Eur J Hum Genet 1999; 7: 748-756.

19 Bartsch O, Nemecková M, Kocárek E et al: DiGeorge/velocardiofacial syndrome: FISH studies of chromosomes 22q11 and 10p14, and clinical reports on the proximal 22q11 deletion. Am J Med Genet 2003; 117A: 1-5.
20 Walter S, Sandig K, Hinkel GK et al: Subtelomere FISH in 50 children with mental retardation and minor anomalies, identified by a checklist, detects 10 rearrangements including a de novo balanced translocation of chromosomes 17p13.3 and 20q13.33. Am J Med Genet 2004; 128A: 364-373.

21 Kim UJ, Shizuya H, Kang HL et al: A bacterial artificial chromosome-based framework contig map of human chromosome 22q. Proc Natl Acad Sci USA 1996; 93: 6297-6301.

22 Yokoyama Y, Sakuragawa N: Improved simple generation of GTG-band specific painting probes. Cytogenet Cell Genet 1995; 71: $32-36$.

23 Carlson C, Sirotkin H, Pandita R et al: Molecular definition of $22 \mathrm{q} 11$ deletions in 151 velo-cardio-facial syndrome patients. Am J Hum Genet 1997; 61: 620-629.

24 Edelmann L, Pandita RK, Spiteri E et al: A common molecular basis for rearrangement disorders on chromosome 22q11. Hum Mol Genet 1999; 8: 1157-1167.

25 Shaikh TH, Kurahashi H, Saitta SC et al: Chromosome 22-specific low copy repeats and the 22q11.2 deletion syndrome: genomic organization and deletion endpoint analysis. Hum Mol Genet 2000; 9: 489-501.

26 Babcock M, Pavlicek A, Spiteri E et al: Shuffling of genes within low-copy repeats on 22q11 (LCR22) by Alu-mediated recombination events during evolution. Genome Res 2003; 13: $2519-2532$

27 Fryns JP, De Backer D, Lemli L, Pedersen JC, Van den Berghe H: Partial duplication of the long arm of chromosome 22 (22q 13) with complete 22 trisomy phenotype. Acta Paediatr Belg 1980; 33: 125-127.

28 Knoll JHM, Asamoah A, Pletcher BA, Wagstaff J: Interstitial duplication of proximal 22q: phenotypic overlap with cat eye syndrome. Am I Med Genet 1995; 55: 221-224.

29 Lindsay EA, Shaffer LG, Carrozzo R, Greenberg F, Baldini A: De novo tandem duplication of chromosome segment 22q11-q12: clinical, cytogenetic, and molecular characterization. Am J Med Genet 1995; 56: 296-299.

30 Shaikh TH, Budarf ML, Celle L, Zackai EH, Emanuel BS: Clustered $11 \mathrm{q} 23$ and 22q11 breakpoints and 3:1 meiotic malsegregation in multiple unrelated $\mathrm{t}(11 ; 22)$ families. Am J Hum Genet 1999; 65: $1595-1607$.

31 Funke B, Edelmann L, McCain N et al: Der(22) syndrome and velo-cardio-facial syndrome/DiGeorge syndrome share a $1.5-\mathrm{Mb}$ region of overlap on chromosome 22q11. Am J Hum Genet 1999; 64: $747-758$.

32 Ensenauer RE, Adeyinka A, Flynn HC et al: Microduplication 22q11.2, an emerging syndrome: clinical, cytogenetic, and molecular analysis of thirteen patients. Am J Hum Genet 2003; 73: $1027-1040$ 